\title{
ANALISIS KESALAHAN MAHASISWA TEKNIK ELEKTRO DALAM MENYELESAIKAN SOAL MATEMATIKA I
}

\author{
Riska Novia Sari ${ }^{1}$ \\ Universitas Riau Kepulauan \\ riskanovia30@gmail.com
}

\begin{abstract}
ABSTRAK. Tujuan penelitian ini adalah untuk mengetahui kesalahan yang dilakukan oleh mahasiswa Program Studi Teknik Elektro dalam menyelesaikan soal matematika I pada materi sistem bilangan riil. Penelitian ini merupakan penelitian deskriptif. Adapun subjek penelitian yaitu mahasiswa Program Studi Teknik Elektro semester l yang berjumlah 27 orang. Teknik pengumpulan data yang digunakan yaitu berupa tes uraian dengan jumlah 8 soal. Jawaban mahasiswa kemudian dianalisis dan dihitung persentase kesalahan-kesalahan yang dilakukan diantaranya yaitu kesalahan konsep, kesalahan perhitungan dan kesalahan prosedur. Hasil penelitian diperoleh bahwa 1) persentase kesalahan konsep yang dilakukan mahasiswa sebesar $18,38 \%$, 2) persentase kesalahan perhitungan yakni sebesar $23,62 \%$, dan 3) persentase kesalahan prosedur yaitu sebesar $11,10 \%$. Sehingga dapat disimpulkan bahwa kesalahan yang paling dominan dilakukan oleh mahasiswa dalam menyelesaikan soal matematika I pada materi sistem bilangan riil yaitu kesalahan perhitungan.
\end{abstract}

Kata Kunci: Kesalahan perhitungan, Kesalahan konsep, Kesalahan prosedur, Matematika I

\section{PENDAHULUAN}

Mata kuliah matematika I merupakan mata kuliah wajib bagi mahasiswa Program Studi Teknik Elektro, khususnya di Fakultas Teknik Universitas Riau Kepulauan. Materi yang dibahas pada mata kuliah ini sama dengan materi Kalkulus I diantaranya yaitu sistem bilangan riil, fungsi dan grafiknya, limit fungsi, kekontinuan fungsi, turunan fungsi, turunan implisit, turunan parametrik, turunan tingkat tinggi, aplikasi turunan meliputi: garis singgung/normal, aturan l'hopital, nilai ekstrim, menggambar grafik. Dengan mempelajari mata kuliah matematika I ini diharapkan mahasiswa dapat menerapkan dan mengaplikasikan konsepnya untuk mata kuliah selanjutnya yaitu mata kuliah matematika II dan III serta dapat memecahkan suatu permasalahan yang berkaitan dengan kehidupan sehari-hari. Sebagai salah satu mata kuliah prasyarat, maka diharapkan penguasaan konsep mahasiswa terhadap mata kuliah matematika I ini baik dan memperoleh hasil belajar yang baik pula. Namun berdasarkan pengalaman peneliti sebagai dosen yang mengampu mata kuliah matematika I, hasil belajar yang diperoleh mahasiswa masih belum sesuai dengan yang diharapkan. Masih banyak mahasiswa yang memperoleh skor kurang dari atau sama dengan 45 . Berikut 
persentase nilai Ujian Tengah Semester (UTS) dan Ujian Akhir Semester (UAS) yang diperoleh mahasiswa Teknik Elektro Semester I.

Tabel 1. Nilai UTS dan UAS Mata Kuliah Matematika I

\begin{tabular}{ccc}
\hline \multirow{2}{*}{ Rentang Skor } & \multicolumn{2}{c}{ Persentase } \\
\cline { 2 - 3 } & UTS & UAS \\
\hline$\geq 81$ & $7,40 \%$ & $29,63 \%$ \\
\hline $68-80$ & $14,81 \%$ & $18,51 \%$ \\
\hline $56-67$ & $11,11 \%$ & $18,51 \%$ \\
\hline $46-55$ & $29,93 \%$ & $3,70 \%$ \\
\hline$\leq 45$ & $36,75 \%$ & $29,65 \%$ \\
\hline
\end{tabular}

Berdasarkan Tabel I di atas, terlihat persentase mahasiswa yang memperoleh skor kurang dari 45 lebih besar dibandingkan dengan yang lainnya baik itu pada UTS maupun UAS. Hal ini menunjukkkan masih rendahnya pencapaian hasil belajar mahasiswa pada mata kuliah matematika I. Disamping rendahnya hasil belajar, masih banyak mahasiswa yang melakukan kesalahan-kesalahan dalam mengerjakan soal yang diberikan. Kesalahan-kesalahan dalam pengerjaan soal inilah yang diduga mengindikasikan rendahnya penguasaan siswa terhadap materi yang diberikan sehingga berdampak terhadap hasil belajar. Hal ini senada dengan pendapat Arigayati (2017). Sehingga peneliti tertarik untuk melakukan penelitian guna menganalisis jenis-jenis kesalahan yang dilakukan oleh mahasiswa dalam mengerjakan soal matematika I. Dengan mengetahui jenis-jenis kesalahan yang dilakukan oleh mahasiswa, dosen sebagai pengampu mata kuliah diharapkan dapat memberikan solusi yang tepat agar dapat diperbaiki dan tidak melakukan kembali kesalahan yang sama oleh mahasiswa berikutnya (McGuire, 2013; Kingsdorf, S., and Krawec, J, 2014).

Ardiawan (2015) menyatakan kesalahan merupakan suatu bentuk penyimpangan terhadap jawaban yang sebenarnya yang bersifat sistematis. Selanjutnya Hudoyo (dalam Arigayati, 2017) membagi kesalahan yang dilakukan oleh mahasiswa yaitu kesalahan konsep, kesalahan prosedur, dan kesalahan komputasi. Sedangkan Imswatama \& Muhassanah (2016) dalam penelitiannya menemukan kesalahan yang dilakukan oleh mahasiswa terdiri dari kesalahan konsep, strategi, hitung, dan sistematik. Rosmaiyadi (2018) membagi kesalahan-kesalahan yang dilakukan oleh mahasiswa menjadi kesalahan konsep, kesalahan dalam menghitung, penyimpangan algoritma, kesalahan tanda, jawaban sembarang, dan mengerjakan jawaban tidak lengkap. Adapun hasil penelitian Abidin (2012) menemukan kesalahan yang dilakukan mahasiswa dalam mengerjakan soal trigonometri dan kalkulus I terdiri dari kesalahan fakta, kesalahan keterampilan, kesalahan konsep, dan kesalahan prinsip. Sedangkan Agustyaningrum, dkk (2018) dalam penelitiannya membagi kesalahan mahasiswa dalam menyelesaikan soal struktur aljabar menjadi kesalahan konsep, kesalahan komputasi dan kesalahan kecerobohan (careless).

Berdasarkan kategori kesalahan-kesalahan yang dilakukan oleh mahasiswa di atas, selanjutnya dalam penelitian ini kesalahan-kesalahan yang dilakukan mahasiswa Program Studi Teknik Elektro dalam menyelesaikan soal Matematika I 
pada materi sistem bilangan riil terdiri dari kesalahan konsep, kesalahan perhitungan, dan kesalahan prosedur. Arigayati (2017) mendeskripsikan kesalahan konsep sebagai pengetahuan konsep yang tidak tepat, salah dalam mengklarifikasikan contoh-contoh dalam konsep dalam keraguan terhadap konsep-konsep yang berbeda. Kesalahan perhitungan yaitu mahasiswa tidak melakukan perhitungan atau salah dalam melakukan perhitungan (Rahimah, 2012). Kesalahan prosedur yang dimaksud dalam penelitian ini adalah ketidaksesuaian langkah-langkah dalam menjawab masalah sehingga tidak ada kejelasan tata letaknya dalam proses menemukan jawaban.

\section{METODE PENELITIAN}

Penelitian ini merupakan penelitian deskriptif yang bertujuan untuk mendeskripsikan kesalahan mahasiswa dalam menyelesaikan soal sistem bilangan riil pada mata kuliah Matematika I. adapun subjek dalam penelitian ini yaitu mahasiswa Program Studi Teknik Elektro, Fakultas Teknik, Universitas Riau Kepulauan yang berjumlah 27 orang. Pengumpulan data pada penelitian ini menggunakan instrument berupa tes hasil belajar. Tes yang diberikan berupa tes uraian yang terdiri dari 8 soal pada materi sistem bilangan riil. Tes ini diberikan untuk mengetahui letak kesalahan mahasiswa dalam mengerjakan soal yang diberikan. Setelah tes diberikan, jawaban mahasiswa di analisis dan dicari persentase masing-masing kesalahan dengan menggunakan rumus sebagai berikut.

$$
P=\frac{f}{N} \times 100 \%
$$

Keterangan:

$\mathrm{P} \quad=$ Persentase

$\mathrm{F} \quad=$ Frekuensi siswa yang melakukan kesalahan

$\mathrm{N} \quad=$ Total kesalahan

\section{HASIL DAN PEMBAHASAN}

Jawaban hasil tes mahasiswa dalam mengerjakan soal matematika I diperiksa dan diperoleh persentase masing-masing kesalahan yang dilakukan oleh mahasiswa sebagai berikut.

Tabel 2. Hasil Persentase Rata-rata Kesalahan Mahasiswa

\begin{tabular}{ccccc}
\hline No Soal No & \multicolumn{3}{c}{ Persentase Kesalahan } \\
\cline { 3 - 5 } & $\begin{array}{c}\text { Konsep } \\
(\%)\end{array}$ & $\begin{array}{c}\text { Perhitungan } \\
(\%)\end{array}$ & $\begin{array}{c}\text { Prosedur } \\
(\%)\end{array}$ \\
\hline 1 & $1 \mathrm{a}$ & 8,67 & 55,20 & 12,33 \\
\hline 2 & $1 \mathrm{~b}$ & 0 & 27,00 & 8,5 \\
\hline 3 & $1 \mathrm{c}$ & 0 & 49,32 & 8,5 \\
\hline 4 & $2 \mathrm{a}$ & 10,13 & 12,5 & 33,33 \\
\hline 5 & $2 \mathrm{~b}$ & 8,67 & 8,33 & 26,20 \\
\hline 6 & $3 \mathrm{a}$ & 37,52 & 16,33 & 0 \\
\hline
\end{tabular}




\begin{tabular}{ccccc}
\hline No & Soal No & \multicolumn{3}{c}{ Persentase Kesalahan } \\
\cline { 3 - 5 } & $\begin{array}{c}\text { Konsep } \\
(\%)\end{array}$ & $\begin{array}{c}\text { Perhitungan } \\
(\%)\end{array}$ & $\begin{array}{c}\text { Prosedur } \\
(\%)\end{array}$ \\
\hline 7 & $3 b$ & 20,00 & 4,17 & 0 \\
\hline 8 & $3 \mathrm{c}$ & 72,23 & 8,83 & 0 \\
\hline & Jumlah & 147,09 & 165,35 & 88,86 \\
\hline \multicolumn{2}{c}{ Rata-rata } & 18,38 & 23,62 & 11,10 \\
\hline
\end{tabular}

Berdasarkan Tabel 2 di atas terlihat bahwa rata-rata kesalahan mahasiswa dalam menyelesaikan soal matematika I memiliki persentase tertinggi yaitu kesalahan perhitungan dan diikuti oleh kesalahan konsep dan kesalahan prosedur. Untuk soal no 1a, 1b, dan 1c kesalahan yang paling banyak dilakukan yaitu kesalahan perhitungan. Sedangkan untuk soal 3a, 3b, dan $3 c$ kesalahan paling dominan dilakukan mahasiswa yaitu kesalahan konsep. Selanjutnya untuk soal nomor 2 kesalahan tertinggi pada kesalahan prosedur. Berikut akan ditampilkan beberapa contoh kesalahan yang dilakukan oleh mahasiswa.

\section{Kesalahan Konsep}

Kesalahan konsep yang paling dominan ditemukan yaitu mahasiswa belum memahami konsep bilangan rasional dan bilangan irrasional. Sehingga ketika diberikan soal berupa membedakan mana yang termasuk bilangan rasional dan irrasional banyak mahasiswa yang keliru, berikut soal dan contoh jawaban yang diberikan oleh mahasiswa.

\section{Soal:}

Mana diantara bilangan berikut yang termasuk bilangan rasional dan irrasional.
a. $-\sqrt{9}$
b. $(3 \sqrt{2})(5 \sqrt{2})$
c. $(1+\sqrt{3})^{2}$
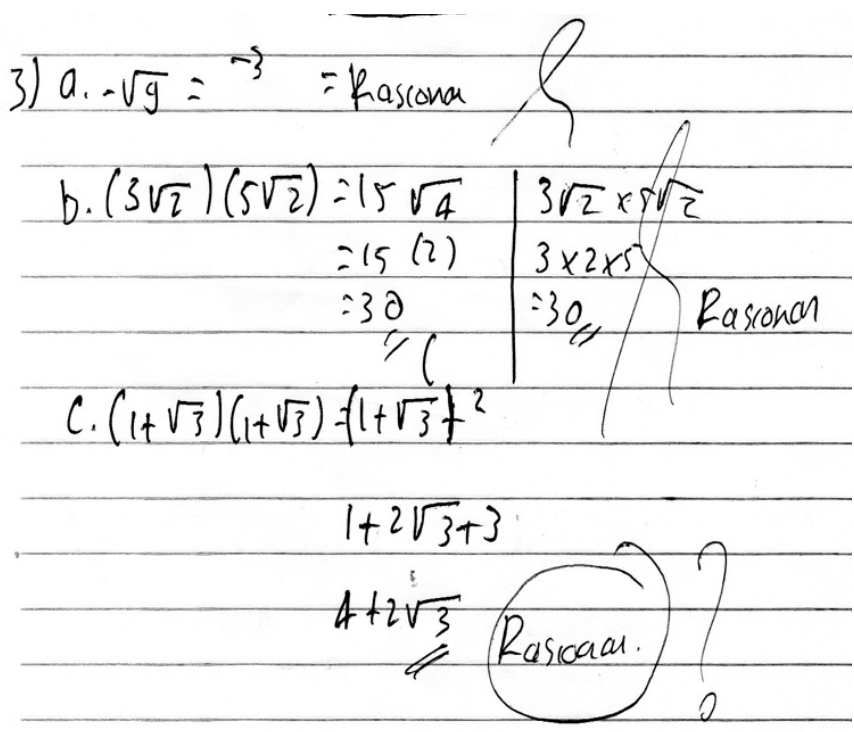

Gambar 2. Jawaban Mahasiswa I 
Jawaban yang diberikan salah seorang mahasiswa seperti terlihat pada Gambar 2 di atas untuk soal bagian a dan b sudah benar sedangkan pada bagian c siswa menjawab termasuk bilangan rasional padahal bilangan tersebut adalah bilangan irrasional. Soal nomor 3 bagian c inilah yang memiliki persentase kesalahan konsep paling tinggi dibandingkan soal lainnya yaitu sebesar $72,23 \%$.

\section{Kesalahan Perhitungan}

Kesalahan perhitungan yang paling banyak dilakukan oleh mahasiswa adalah dalam melakukan operasi pengurangan atau penjumlahan bentuk pecahan. Selain itu mahasiswa juga keliru dalam mengalikan dua buah bilangan dibawah tanda akar. Berikut beberapa contoh jawaban mahasiswa.

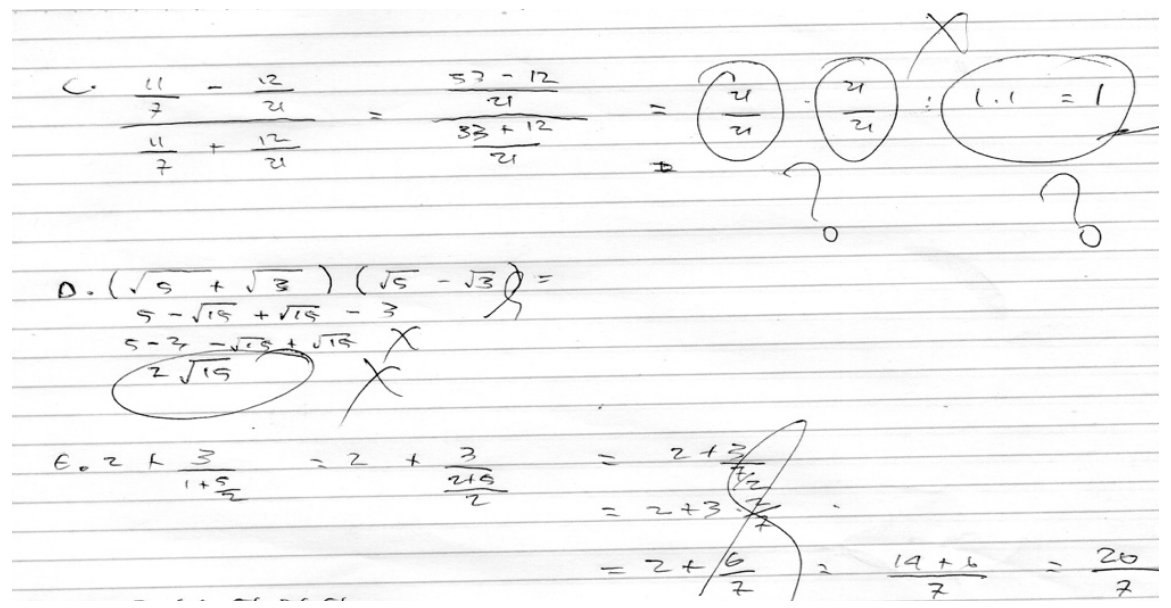

Gambar 3. Jawaban Mahasiswa 2

$$
\begin{aligned}
& \text { 1. } c=\frac{11}{7}-\frac{12}{21} \\
& \left.\frac{71}{7}+\frac{\frac{12}{21}}{21}=\frac{\frac{12}{21}}{\frac{54}{21}}=\frac{252}{1.134}\right]_{0}^{2} \\
& \begin{aligned}
d=(\sqrt{5}+\sqrt{3})(\sqrt{5}-\sqrt{3}) & =5-\sqrt{15}+\sqrt{155}-3 \\
& =5-3 \\
& =2
\end{aligned} \\
& \text { e. } 2+\frac{3}{1+\frac{5}{2}}=2+\frac{3}{\frac{7}{2}}=2+\frac{6}{7}=\frac{14+6}{7}=\frac{20}{7}
\end{aligned}
$$

Gambar 4. Jawaban Mahasiswa 3

Jawaban kedua mahasiswa pada Gambar 3 dan 4 di atas untuk soal yang pertama keliru. Mahasiswa salah dalam melakukan penjumlahan bentuk pecahan. 
Mahasiswa 3 misalnya dalam menjumlahkan $\frac{11}{7}+\frac{12}{21}=\frac{54}{21}$, padahal jawaban yang benarnya adalah $\frac{11}{7}+\frac{12}{21}=\frac{45}{21}$. Sedangkan mahasiswa 2 sudah benar dalam mengerjakan langkah yang pertama namun keliru dalam melakukan perhitungan dalam langkah berikutnya sehingga memperoleh hasil akhir yang salah.

\section{Kesalahan Prosedur}

Kesalahan prosedur yang dilakukan mahasiswa yaitu tidak menuliskan langkahlangkah memperoleh jawaban, mereka langsung menuliskan jawaban. Selain itu jawaban yang diberikan juga keliru. Hal ini terlihat pada Gambar 5 berikut, mahasiswa hanya menuliskan jawaban soal tanpa menuliskan tahapan memperoleh jawaban tersebut. jawaban mahasiswa pada Gambar 6 untuk bagian b secara prosedur sudah benar, namun mahasiswa keliru dalam melakukan perhitungan khususnya operasi pengurangan.

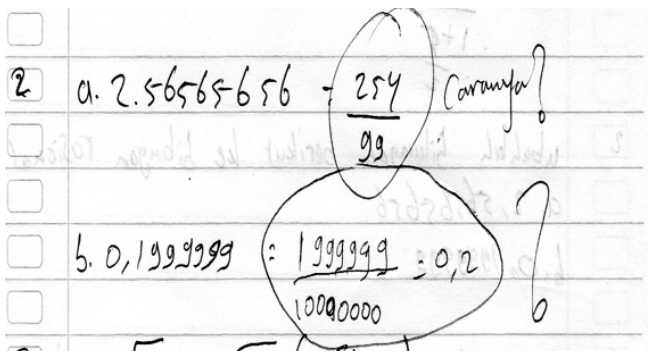

Gambar 5. Jawaban Siswa 4

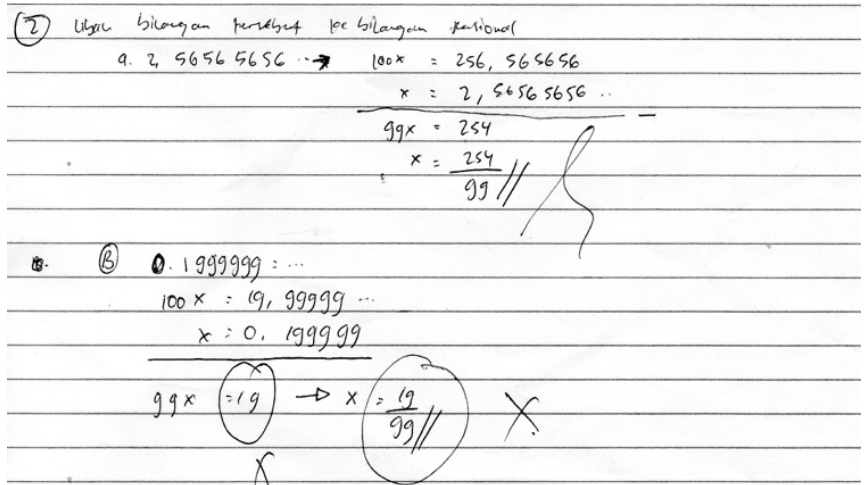

Gambar 6. Jawaban Siswa 5

\section{KESIMPULAN}

Berdasarkan hasil penelitian dapat disimpulan bahwa persentase kesalahan terbanyak yang dilakukan oleh mahasiswa dalam menyelesaikan soal matematika I pada materi Sistem Bilangan Riil yaitu kesalahan perhitungan yakni sebesar $23,62 \%$, kemudian diikuti oleh kesalahan konsep yakni sebesar $18,38 \%$ dan terakhir yaitu kesalahan prosedur yaitu sebesar 11,10\%.

\section{DAFTAR PUSTAKA}

Abidin, Zainal. 2012. Analisis Kesalahan Mahasiswa Prodi Pendidikan Matematika Fakultas Tarbiyah IAIN Ar-Raniry dalam Mata Kuliah Trigonometri dan Kalkulus I. Jurnal IImiah DIDAKTIKA. 13(1). 183 - 196. 
Agustyaningrum, N., Abadi, A. M., Sari, R. N., \& Mahmudi, A. 2018. An Analysis of Students' Error in Solving Abstract Algebra Tasks. IOP Conf. Series: Journal of Physics; Conf. Series 1097 (2018) 012118.

Ardiawan, Yadi. 2015. Analisis Kesalahan Mahasiswa dalam Menyelesaikan Induksi Matematika di IKIP PGRI Pontianak. Jurnal Pendidikan Informatika dan Sains. 4(1). $147-163$.

Arigiyati, Tri Astuti. 2017. Identifikasi Kesalahan Mahasiswa dalam Menyelesaikan Soal Pengantar Probabilitas. Jurnal Penelitian Pendidikan. 9(1). 1363 - 1368.

Imswatama, A \& Muhassanah, N. 2016. Analisis Kesalahan Mahasiswa dalam Menyelesaikan Soal Geometri Analitik Bidang Materi Garis dan Lingkaran. Suska Journal of Mathematics Education. 2(1). 1 - 12.

Kingsdorf, S., and Krawec, J. 2014. Error Analysis of Mathematical Word Problem Solving Across Students with and without Learning Disabilities. Learning Disabilities Research and Practice, 29(2). 66-74.

McGuire, Patrick. 2013. Using Online Error Analysis Items to Support Preservice Teachers' Pedagogical Content Knowledge in Mathematics. Contemporary Issues in Technology and Teacher Education. 13(3). 207 - 218.

Rosmaiyadi. 2018. Analisis Kesalahan Penyelesaian Soal Aljabar pada Mahasiswa Program Studi Pendidikan Matematika STKIP Singkawang. Journal Pendidikan Matematika. 12(1). $59-70$.

Rahimah, Dewi. 2012. Identifikasi Kesalahan Mahasiswa dalam Menyelesaikan SoalSoal Pokok Bahasan Integral pada Mata Kuliah Kalkulus Integral. Jurnal Exacta. 10(1). $89-97$. 